\title{
Utilization Museum Vredeburg as a Learning Resources Civic Education for Improvement Character Citizenship Communities
}

\author{
Ambar Sari ${ }^{1}$ and Marzuki ${ }^{2}$ \\ Postgraduate Education in Pancasila and Citizenship \\ Universitas Negeri Yogyakarta, Indonesia \\ 19ambarsari.2018@student.uny.ac.id, ${ }^{2}$ marzuki@uny.ac.id
}

\begin{abstract}
Citizenship education is obtained by the public through formal academic schooling through the subjects of Pancasila and Civic education. After graduating from High School (SMA), citizenship education will be obtained if someone goes on to the university level. Citizenship education informal education from elementary school to tertiary education is limited only in time and space, whereas to apply the character of citizenship requires a lot of activities outside of school hours or lectures. Lots of space and scope to be a source of citizenship education learning, one of which is a museum. The museum has cultural value, struggle and high potential knowledge which is a source of citizenship education for the community. In this study, researchers will focus on the use of the Fort Vredeburg struggle museum as a source of citizenship education learning in the community. The research method used is qualitative, in collecting data using interview methods, documentation and some data documents about the Fort Vredeburg Museum. The purpose of this study is to explore that the artistic buildings and museum collections of Fort Vredeburg which have high historical value can have great potential as a source of learning citizenship education in the community.
\end{abstract}

Keywords: Fort Vredeburg Museum, Nationality, Character.

\section{INTRODUCTION}

In improving the quality of education in Indonesia, efforts have been made through Law No. 20 of 2003 concerning the National Education System Article 1 paragraph (1) that: "Education is a conscious and planned effort to create an atmosphere of learning and learning process so that students actively develop their potential to have religious-spiritual strength, self-control, personality, intelligence, noble character and the skills needed by himself, the nation and the country ". Education is an effort to guide, direct and give learning to someone to be better, through cognitive, affective and psychomotor aspects [1].

The teaching and learning process of formal schools in Indonesia is indeed carried out in the classroom/room of each school. An Tradition by Anglo Saxon gives the view that teaching and learning outside the classroom/room will provide adventure experiences and further enhance leadership skills, such experiences are provided by the center of a specially built 
outdoor space [2]. In the Scandinavian context, the teaching and learning process outside the classroom/room will involve the nearest natural or cultural landscape [3]. Education in Indonesia is expected to be able to make the community a consistent citizen of maintaining the Unitary State of the Republic of Indonesia through efforts to shape the citizenship character of students that are useful for themselves, the nation and the state. Character education has a higher meaning than moral education which teaches what is right and what is wrong and instills habits about what is good, so students become understanding, able to feel, and able to do what is good. Citizenship Education is one of the missions carried out by Citizenship Education. Other missions are political education / democratic education, legal education, human rights education, and anti-corruption education [4]. Citizenship character education should not only be obtained in formal schools or universities, in other words, there is a lot of space for the community to get a contribution to learn citizenship education, one of them through museums.

Museum in Yogyakarta, 57 museums are still managed by both private and government. The museum is a physical building architectural building in which there are objects of artifacts. There are several classifications of museums, namely art museums, science museums or historic museums that are exhibited to the elements of society [5]. The understanding of Falk \& Dierking is reinforced by Komarac, which gives an understanding of the museum as part of a broad entertainment and cultural environment, which is dominated by visitors who have high demands, who seek deep experience (edutainment) and time-saving arrangements [6]. In Yogyakarta, museums included in the struggle museum classification are the Museum of Struggle, the Army Museum, the Museum of the JogjaKembali Monument, the Great General Museum H. Soeharto, the Wanitatama Movement Museum, the Sandi Museum Vredeburg Museum.

The Fort Vredeburg Museum has a dancing identity from other struggle type museums because the history of the Vredeburg Museum greatly influenced the civilization of the people in Yogyakarta, even in Indonesia. The Vredeburg Fort Museum is located in the zero kilometer area of the center of Yogyakarta City. The Vredeburg Museum is also surrounded by old Dutch heritage buildings such as in the west there is GedungAgung (a former resident's house), in the south there are a Ngejaman church (GPIB Margamulya), BNI Bank Office 1946, Post Office and Bank Indonesia offices, in the east and to the west there is a traditional shopping center namely the Beringharjo market and Malioboro street. The Vredeburgfort museum consists of an educational element as well as a place for recreation. The historical background of the city of Yogyakarta and the capital of the Republic of Indonesia are inseparable from the history of the existence of the Vredeburg Fort Museum. In the Vredeburg Fort Museum it contains dioramas and minima of all historical processes, for example when the Renville Agreement was signed, Sudirman was appointed as the Commander in Chief of the Armed Forces, the implementation of the UtomoBoedi Congress. The collection presented is an object that has been used during history, such as a typewriter owned by Surjopranoto. This typewriter was used by Surjopranoto to lead sugar factory workers in Yogyakarta to strike as a form of inaction with the current Dutch injustice. The history began from the Diponegoro War (1825-1830), the Japanese occupation of Yogyakarta, the Dutch Military Aggression II, and the signing of the Renville Agreement by the Indonesian people until the sovereignty of the United Republic of Indonesia (RIS) on 27 December 1949. The history of the struggle at the Vredeburg Fort Museum began Indonesia returned to the Unitary State of the Republic of Indonesia and ended when the New Order began.

One method that can be done by teachers to provide Citizenship Education learning is through the method of visiting the Vredeburg museum. learning by visiting a museum is 
already a number of schools that do but are not optimal because it is constrained by the minimal learning hours and location of schools that may be far from the location of the museum. The museum is a place to store many collections that can be used as integrated learning resources that provide direct experience for students. Concrete learning resources can be used to facilitate students' understanding of the material that supports the implementation of learning in schools [7].Learning activities carried out in the museum will provide a new atmosphere and different from the atmosphere of learning in the classroom. A new atmosphere to increase students' motivation to participate in learning activities, so students are engaged to be directly involved in learning activities actively, it is hoped that learning objectives can be achieved optimally [8].

Based on the description above, it is important to do in-depth research related to informal education through the museum as a source of citizenship education learning, including the use of the Fort Vredeburg museum as a source of citizenship education learning to improve the character of citizenship in the community.

\section{METHOD}

This research uses a qualitative approach by applying the case study method. Research with case studies will result in in-depth agreements about the completeness and variance of the phenomenon under study. The advantage of this case study is that the researcher will focus on context and process [9]. This research was conducted at the BentengVredeburg museum in Yogyakarta, Indonesia. The findings of this study can be used as hypotheses and theories in learning citizenship education resources through the Fort Vredeburg Museum. Also, it can provide an understanding that the building, as well as the buildings and environment of the Fort Vredeburg museum, become a means of learning citizenship education outside the classroom/room able to have a positive impact on the character of citizenship. Data sources are 1) informants of museum visitors and educators of the Vredeburg Fort Museum 2) events related to the process of the existence of the Vredeburg Fort museum, and 3) documents, obtained from several collections of the Fort Vredeburg Museum. In collecting data, the authors have collected documents as literature studies, conducted in-depth interviews, and field observations [10]. Many participants who were visitors and museum managers were successfully interviewed through a depth interview with the help of a semi-structured interview guide.

\section{RESULT AND DISCUSSION}

The understanding used by Anglo Saxon literature that is transferred to the Scandinavian context is a learning process based outside of school, then in this study will explain that the museum is also able to be a source of learning for the community, not only focusing on recreational visits inside the museum, but in terms of both collections and the structure of the building, the BentengVredenburg museum holds a story that can be a learning of citizenship character in the community [11].

The vision of the Vredeburg Fort Museum is to make the museum as a Center for the preservation of historical values and the struggle towards the formation of a characterized Indonesian society. In this vision implies that the museum wants to be the center of activities to maintain the integrity of the destruction of the values and struggles of Indonesian people who have high national insight. If the vision is elaborated, then there are 4 main visions of the Vredeburg Fort Museum, 1) The preservation center, the center of community activities in preserving historical values as well as national insights to prevent extinction. 2) the value of 
history and struggle, gives a valuable meaning that is used as valuable learning from the past, namely history and the spirit of the nationalist struggle. 3) the people of Indonesia, those who recognize Indonesia as their homeland and shed blood and are ready to be loyal to all legal products in Indonesia. 4) Characterized, the community is expected to have the ability to understand identity and have a strong national outlook. In realizing the vision, the Fort Vredeburg Museum certainly has a mission 1) The realization of the preservation of objects and historical values of the struggle of the Indonesian people through physical preservation activities/collections and character values, 2) the role of the museum as a source of research so that informed information can be realized 3) realization of pleasant educational services in the museum that is the element of education (education) and entertainment (edutainment), so that all activities in the Vredeburg Fort museum must be educational and entertainment [12].

\subsection{Facility for learning citizenship education resources}

The Vredeburg Fort Museum was built in 1760 by the Dutch Government, originally its name was not Vredeburg but Rustenburg Fort (resting fortress). The initial purpose of building this fort was used for the Dutch army to withstand attacks from the Yogyakarta Palace and become the military headquarters of the Republic of Indonesia Army. The form of the Vredeburg Fort Museum is square, on all four corners, there is a guard room (select / bastion), namely Jayapurusa (northeast side), Jayawisesa (on the northwest side), Jayaprakosaningprang (southwest side), and Jayaprajitna (southeast side). Fort Vredeburg is surrounded by a moat, a lift bridge, and a large, solid wall. The Vredeburg Landscape Museum has 55 dioramas in 4 rooms. The museum's masterpiece collection is the Vredeburg Fort building which is a cultural heritage object with Dutch architectural buildings. The existence of the library consists of a collection of history books, audio-visual room, and group study rooms.

In the 21 st century in this digital era, people visiting museums cannot be separated from smartphones in their hands, small screens as the focus and their lenses. The impact of digitalism has touched scientific disciplines, including museums. Some museums experience authentic changes and transformations to be able to compensate for the rapidly developing digital situation. [13]. Digitization of collections, museum history, studies and has been implemented in the Fort VredeburgMuseum. The entire collection room is equipped with the digitization of the collection, starting with the barcode of each collection so that visitors who are comfortable with a smartphone can access the material in the collection. The Vredeburg Fort museum collection by Gallery Systems (Management Software). The value of patriotism in the Fort Vredeburg museum is also digitalized by the presence of a game that is displayed with a 21-inch screen, the game invites the public to refresh with the shooting as a warrior is doing a war.

The museum does store a lot of cultural history of civilization, but the presence of their technology is no longer considered a cultural authority, even though the museum is in the colonial era but as an institution with social responsibility [14]. Submission of the Vredeburg Fort museum relating to cultural values is increasingly performative by providing a useful framework for the usefulness of contemporary museums. The packaging of the Vredebyrg museum in conveying cultural values to the value of citizenship does not only lie in the data collection, but various activities are facilitated by the museum manager BentngVredeburg. Some facilities include 1) seminar room, 2) exhibition room, 3) performance room, all facilities provided by the Fort Vredeburg museum become an alternative place for various exhibition activities, seminars, discussions, meetings, and training. 


\subsection{Activities in the use of museum Vredeburg as a source of citizenship education learning}

The citizenship education discussed in this study is related to citizenship education conducted at the BentengVredeburg Museum, Yogyakarta, Indonesia. The museum can be used as a source of further citizenship learning from the learning of Pancasila education and citizenship in formal schools. The vision and mission in the Fort Vredeburg museum give room to the community to develop the values of citizenship, so it's not just museums that provide citizenship values. If informal schools the material for citizenship includes more cognitive, then in the museum there will be more effective and psychomotor in the process of increasing the value of citizenship. Studying in a museum that has high historical value has significant potential.

Unlike formal schools and universities, museums have other ways of conveying their mission in the world of education. The Vredeburg Fort Museum serves a wide and effective range of publics from several groups. The manager of the Vredeburg Fort Museum has no difficulty in inviting visitors to learn about the history of nationalism in the Fort Vredeburg Museum because the majority of visitors are stimulated by curiosity and active in museum visits. Vrederbergfort museum has the potential to facilitate historical concepts relating to the struggle of the hero in usurping the independence of the Indonesian people from the invaders. Regarding citizenship values that can improve the citizenship character of Indonesian society, here are some of the values of citizenship obtained: 1) Patriotism and nationalism, 2) please help, 3) selfless help, 4) honesty and 5) cooperation.

Trying to be a place for every activity related to the development of citizenship values, it is proven by the many activities of the community ranging from children to the elderly. Various activities are welcome by the Vredeburg castle museum, some of which are:

- Museum night community

The museum night community was founded in 2012 to invite people from various circles to explore museums and cultural reserves in a fun way. The activities of the museum night community are also provided by the Fort Vredeburg Museum, so the community activities to explore the Fort Vredeburg museum are conducted in the afternoon until evening. The nights of visiting the museum give a different sensation, the packaging is made as attractive as possible by the museum night organizer and museum manager of Vredeburg Fort. The museum's night activities are not only limited to surrounding the museum at night but also many games are presented, such as amazing races, kids in museums, heritage classes, historical discussions, and historical film surgery.

- Cinema Museum

Museum cinemas are shown in the Audio Visual Room, one of the rooms in the Vredeburg Fort Museum. Historical film review is one of the activities that is of interest to the public, watching films that are usually in theaters or malls, now presented at the Fort Vredeburg Museum. Filming of the film at the Fort Vredeburg Museum must have educational and entertainment elements so that historical values and nationality insights, as well as citizenship characters, are not eliminated in this activity, because after the screening the film is continued with discussion to the visitors.

- The museum enters the village

The village entrance museum will be organized by the community around Vredeburg Fort, then it will get a response from the Fort Vredeburg museum which directly participates in the village entrance museum. The community has a plan to explore the area that was passed by General Sudirman, one of the heroes who participated in fighting for the Indonesian 
nation. In this activity, it does not only contain historical values but indirectly provides character education to the community relating to the values of patriotism and nationalism. Also, community cooperation in this activity also fosters cooperation between partners.

- The Museum goes to the School

Museum activities at the school entrance are also carried out by the Fort Vredeburg Museum, by picking up students to visit the museum. This activity aims to invite students to get to know the museum since the beginning, strengthening national identity begins with understanding the nation's history. The game provided by the museum manager attracts the curiosity of students, which over time will be curious about history.

- The Museum Goes to the Mall

Museum activities do not stop at school or activities inside the museum, but the museum provides innovation. The Vredeberg Fortress Museum often exhibits museum collections into malls in Yogyakarta namely Malioboro malls, Transmart, Jogja City Mall and Sleman City Hall. The purpose of this activity is to inform the public about the Fort Vredeburg museum, historical values and national insights to be informed.

- Cross Puzzle (TTS) Revolution

The Vredebeurg Museum also invites people to participate in learning history so that people do not forget the heroes who have fought to defend the Indonesian people. The TTS distributed by the Vredeburg Fort Museum concerns the history of the revolution and is related to the Fort Vredeburg Museum. TTS is distributed through social media, the community is expected to participate in filling out the quiz, then it is expected to send the right answers, then the museum will draw to determine the winner. In this case the value of the spirit of enthusiasm to answer the TTS, confidence is gained in the activities presented by the Fort Vredeburg Museum.

Using of vredeburg museum as a source of learning Citizenship Education is quite effective, some of the reasons are (1) a large collection of historical relics of the struggle that gives students a sense of curiosity to better learn the love of the country and defending the country, (2) the architecture of the vredeburgfort museum building which is unique and full of historical values make students more curious about the history of the struggle for Indonesia, (3) educator of the fort vredeburg museum which provides a detailed understanding of collections by linking good citizenship values in daily life can make visitors and students better understand the values of citizenship [15]. The activities and museum collections of the Fort Vredeburg can provide effectiveness in learning history and citizenship even though there are obstacles, which are related to time. The extensive collection and buildings in the Fort Vredeburg museum are not enough for one day to study the values in the Fort Vredeburg museum.

\section{CONCLUSION}

The Fort Vredeburg Museum is a struggling museum located in Yogyakarta. This museum can become an informal community school as a source of citizenship education learning. Collections, forms of buildings, and activities held at the Fort Vredeburg museum strongly support educational goals in Indonesia. Educational learning resources Citizenship is not only informal education, but all spaces can be used as learning resources including the Fort Vredeberg Museum. Some programs of the Vredeburg Fort Museum activities to realize the vision and mission of the Minister of Religion Museum are appropriate to be used as a source of learning Citizenship Education, such as exploring the museum even in days, visiting 
the museum, the Fort Vredeburg Museum entering the village, the museum entering the mall, the museum entering the school and also holding it TekaTeki Cross Revolution through Instagram. Some of these activities are community participation from several groups, ranging from the age of children to the elderly who can learn citizenship education at the Fort Vredeburg Museum. The values of patriotism, nationalism, and nationalism can be felt by visitors to the Fort Vredeburg Museum.

\section{REFERENCES}

[1] M. Yunus. "Development of the Model of Character Education at the Islamic Boarding School in Watangpone". Journal of Research and Multidisciplinary, Vol. 1, No. 1, pp. 110, 2018.

[2] Taylor, C., Power, S., \& Rees, G. Out-of-school learning: The uneven distribution of schoolprovision and local authority support. British Educational Research Journal, 36(6), 1017-1036, 2010.

[3] Bentsen, P., Sødergaard Jensen, F., Mygind, E., \&BarfoedRandrup, T. The extent anddissemination of udeskolein Danish schools. Urban Forestry \& Urban Greening, 9(3), 235-243, 2010

[4] Cholisin. PengembanganKarakterdakannateripembelajaranPkn. Yogyakarta: UNY Press.

[5] J.H. Falk \& L.D Dierking. "The Interactive Experience Model". The Museum Experience. London \&Newyork: Routledge, pp1-10, 2019.

[6] Komarac, T. "A New World for museum marketing? facing the old dilemmas while challenging new market opportunities". Trziste, Vol 26 (2), pp 199-214, 2014.

[7] Anitah, S., dkk. StrategiPembelajaran di SD. Jakarta: Universitas Terbuka, 2010.

[8] Praptiwi. Pemanfaatan museum sebagaisumberbelajar untuk sekolahdasar. The utilization of museums as learning resources for elementary school. Yogyakarta: UniversitasNegeri Yogyakarta, Vol 32 No. 7. 202-211, 2018.

[9] B. Flyvbjerg. (2011). Case study. In N. Denzin \& Y. Lincoln (Eds.), The Sage handbook of qualitativeresearch. Thousand Oaks, CA: Sage, pp. 301-316, 2011.

[10] J. R. Ledford and D. L. Gast. Single Case Research Methodology: Applications in Special Education and Behavioral Sciences. British: Routledge, 2018.

[11] Thorburn, M., \& Allison, P. Are we ready to go outdoors now? The prospects for outdooreducation during a period of curriculum renewal in Scotland. The Curriculum Journal, 21(1),97-108, 2010.

[12] V.Agus, M. Rosyid, Winarni, M. Kurniati\& J. Chusbiantori. "Museum bentengvredeburg Yogyakarta". Pp 2-4, 2019.

[13] Tula, G. \& Jonathan, P. B. "Museums and digitals". Museums and digital culture new perspectives and research. New York: Springer, pp 27-35,2019.

[14]Boyd, C. \& Hughes, R. "Museology, cultural geography, and non-representational". Emotion and the contemporary Museum Development of a geographically-informed approach to visitor evaluation. Australia: Palgrave Macmillan, pp 1-10, 2019.

[15] K. Saddhono, "Integrating culture in Indonesian language learning for foreign speakers at Indonesian universities,” J. Lang. Lit., vol. 6, no. 2, 2015. 